\title{
Hubungan Tingkat Kecemasan dengan Kesiapan Dokter Gigi dalam Menghadapi Pandemi Covid-19
}

\author{
Michelle Wilia, Mia A. Prasetya, Putri Rejeki
}

\author{
Program Studi Sarjana Kedokteran Gigi dan Profesi Dokter Gigi Fakultas Kedokteran \\ Universitas Udayana, Bali, Indonesia \\ E-mail: michellewilia27@gmail.com \\ Disubmisi: 21 November 2021; direvisi: 5 Desember 2021; diterima 19 Desember 2021
}

\begin{abstract}
Coronavirus disease 2019 (Covid-19) can cause respiratory problems and affect all ages. The nature of the transmission and the mortality rate of this viral infection bring about anxiety among health workers, inter alia, dentists because they have a high risk of contracting Covid-19. This study was aimed to determine the relationship between anxiety levels and the preparedness of dentists in facing the Covid-19 pandemic. This was an analytical study with a cross-sectional design. A quantitative study was conducted using a questionnaire that has been structured and tested for its validity and reliability. The questionnaire was divided into two parts, as follows: demographic data and levels of anxiety. Data were analyzed univariately and bivariately with the Spearman correlation test. There were 276 dentists in Bali as respondents who participated in this study. The results showed that the highest level of anxiety was moderate anxiety $(54.3 \%)$ and there was a relationship between level of anxiety and the number of screening and patient settings with a p-value of $0.034(\mathrm{p}<0.05)$. In conclusion, there is a relationship between level of anxiety and the dentist's preparedness in the form of number of screening and patient setting to face the Covid-19 pandemic in Bali.
\end{abstract}

Keywords: Covid-19; dentist; anxiety

\begin{abstract}
Abstrak: Coronavirus disease 2019 (Covid-19) dapat menyebabkan gangguan pernapasan dan menyerang segala rentang usia. Sifat transmisi dan tingkat mortalitas infeksi virus ini menyebabkan kecemasan di kalangan petugas kesehatan, salah satunya dokter gigi karena memiliki risiko tinggi tertular Covid-19. Penelitian ini bertujuan untuk mengetahui hubungan antara tingkat kecemasan dan kesiapan dokter gigi dalam menghadapi pandemi Covid-19. Jenis penelitian ialah analitik dengan desain potong lintang. Penelitian kuantitatif dilakukan menggunakan kuesioner yang telah disusun dan diuji validitas dan reliabilitasnya. Kuesioner dibagi menjadi dua bagian yaitu data demografi dan tingkat kecemasan dokter gigi. Hasil data dianalisis secara univariat dan bivariat menggunakan uji korelasi Spearman. Terdapat 276 dokter gigi di Bali yang berpartisipasi dalam penelitian ini. Hasil penelitian menunjukkan bahwa tingkat kecemasan paling tinggi ialah kecemasan sedang (54.3\%) dan terdapat hubungan antara tingkat kecemasan dengan jumlah skrining dan pengaturan pasien dalam menghadapi pandemi Covid-19 di Bali dengan $\mathrm{p}=0,034(\mathrm{p}<0,05)$. Simpulan penelitian ini ialah terdapat hubungan antara tingkat kecemasan dengan kesiapan dokter gigi yang dinyatakan dalam jumlah skrining dan pengaturan pasien dalam menghadapi pandemi Covid-19 di Bali.
\end{abstract}

Kata kunci: Covid-19; dokter gigi; kecemasan

\section{PENDAHULUAN}

Wabah coronavirus disease 2019 (Covid-19) disebabkan oleh infeksi severe acute respiratory syndrome coronavirus 2
(SARS-CoV-2) yang muncul pertama kali di kota Wuhan, Cina pada bulan Desember 2019. ${ }^{1,2}$ Infeksi virus ini dapat menyebabkan gangguan pernapasan akut yang menimbul- 
kan sesak nafas berat hingga kematian. ${ }^{3}$ Virus Covid-19 dapat menyerang segala rentang usia melalui metode transmisi aerosol, namun beberapa studi menyatakan bahwa transmisi airborne dapat terjadi pada situasi tertentu. ${ }^{4}$ Sifat transmisi dan tingkat mortalitas dari infeksi virus ini menyebabkan kekhawatiran di kalangan petugas kesehatan, salah satunya dokter gigi. Dokter gigi memiliki risiko yang cukup tinggi terpapar virus SARS-CoV-2 dari pasien karena tindakan yang dilakukan memerlukan dokter gigi untuk bekerja dengan posisi dekat ke mulut pasien. Selain itu, banyak prosedur dalam praktik kedokteran gigi yang menghasilkan aerosol dan droplet berupa campuran air dan air liur atau darah pasien. $^{5}$ Transmisi dapat terjadi melalui kontak langsung saat aerosol terhirup dan melalui kontak tidak langsung dengan menyentuh permukaan yang telah terkontaminasi virus. ${ }^{6}$

Virus Covid-19 telah menjadi keadaan darurat kesehatan masyarakat di lebih dari 200 negara dan diperkirakan sampai November 2021 telah menginfeksi lebih dari 250 juta orang dengan jumlah kematian sekitar 5 juta orang. Indonesia sendiri juga mengalami pandemi semenjak Maret 2020, dan jumlah kasus terus meningkat dan berfluktuasi. ${ }^{7}$ Pada Desember 2020 tercatat sekitar 700 ribu orang terinfeksi di Indonesia dan sebanyak 64 daerah telah masuk kedalam kategori zona merah, termasuk Pulau Bali. ${ }^{8}$ Puncak tertinggi kasus terjadi pada bulan Juli 2021 dengan total 56.757 kasus terkonfirmasi dan setelah itu jumlah penambahan kasus sudah mulai melandai. ${ }^{7}$ Pada November 2021, pulau Bali telah masuk kedalam kategori risiko rendah. ${ }^{9}$

Dalam situasi pandemi sekarang, wajar bagi dokter gigi yang praktik di Bali untuk merasa cemas tertular dari pasien mereka. Dokter gigi yang berada dalam daftar profesi berisiko tinggi terpapar sangat rentan untuk mengembangkan perasaan cemas dalam menghadapi situasi pandemi saat ini. Studi sebelumnya melaporkan reaksi psikologis negatif di antara petugas kesehatan pada saat wabah SARS tahun 2003. Saat ini kekhawatiran yang serupa mengenai kese- hatan fisik, mental, dan penyesuaian psikologis petugas kesehatan mulai muncul. ${ }^{10}$

Kurangnya pemahaman dan persiapan dalam menghadapi pandemi Covid-19 dapat membuat dokter gigi berisiko terkena penyakit dan mengalami masalah psikologis tertentu. ${ }^{11}$ Panduan dokter gigi dalam era new normal yang dikeluarkan oleh Persatuan Dokter Gigi Indonesia (PDGI) menjelaskan bahwa tata kelola ruang praktik, alur dan tata cara pengerjaan pasien serta Alat Pelindung Diri (APD), perlu diatur sedemikian rupa sehingga dapat menurunkan risiko dokter gigi, perawat gigi, pasien, keluarga, dan lingkungan sekitarnya terhadap transmisi Covid-19. Ketentuan-ketentuan ini dimaksudkan untuk melindungi dokter gigi dan tenaga kesehatan pendukung agar tidak tertular Covid-19, serta menghindari adanya infeksi silang saat melakukan praktik kedokteran gigi. ${ }^{12}$

Berdasarkan latar belakang yang telah dipaparkan, penulis tertarik untuk mengetahui hubungan tingkat kecemasan dengan kesiapan dokter gigi dalam menghadapi pandemi Covid -19 di Bali.

\section{METODE PENELITIAN}

Penelitian ini dilaksanakan di Bali selama bulan Agustus-Oktober 2021, menggunakan metode analitik dengan desain potong lintang. Penelitian dan pengumpulan data menggunakan kuesioner (data primer) pada dokter gigi yang praktik selama pandemi COVID-19. Kuesioner tersebut telah dilakukan uji validitas dan reliabilitas. Sampel yang memenuhi kriteria inklusi dan eksklusi berjumlah 276 orang dan dipilih dengan menggunakan teknik consecutive sampling. Kriteria inklusi penelitian ini ialah: dokter gigi yang bersedia mengisi kuesioner hingga akhir dan terlibat dalam penelitian, telah teregistrasi dalam Konsil Kedokteran Indonesia (KKI) dan PDGI, serta memiliki SIP (Surat Ijin Praktik) di wilayah Bali.

Pengumpulan data dilakukan dengan menggunakan kuesioner melalui google forms. Terdapat tiga jenis kuesioner/formulir tertulis yang perlu diisi oleh responden yaitu informed consent, data demografi, dan daftar 
pertanyaan terkait penelitian yang dilakukan. Penulis menjelaskan kepada responden mengenai informed consent atas kesediaan responden menjadi bagian dalam penelitian dan kerahasiaan data dijaga oleh penulis. Daftar pertanyaan terdiri dari sarana dan prasarana kesiapan dokter gigi terkait pandemi COVID-19 dan 19 pertanyaan mengenai kecemasan dalam bentuk pilihan ganda dengan lima pilihan jawaban model Likert. Penelitian ini telah mendapatkan persetujuan dari Komisi Etik Fakultas Kedokteran Universitas Udayana Nomor 2208 NNI 4.2.2.V 11.14 ILT 12021.

\section{HASIL PENELITIAN}

Tabel 1 memperlihatkan bahwa responden penelitian yang memenuhi kriteria inklusi dan eksklusi berjumlah 276 dokter gigi. Persentase tertinggi didapatkan pada jenis kelamin perempuan sejumlah 177 $(64,1 \%)$ responden, kelompok usia 20-30 tahun sejumlah $110(39,9 \%)$ responden, dan tidak memiliki penyakit sistemik penyerta sebanyak $251(90,9 \%)$ responden.

Tabel 2 memperlihatkan persentase sarana dan prasarana kesiapan dokter gigi. Tempat praktik terbanyak yaitu praktik pribadi sebanyak $137(49,6 \%)$ responden dengan lama praktik selama 0-5 tahun sejumlah $114(41,3 \%)$ responden. Sebagian besar responden telah menerima vaksinasi
Covid-19 sejumlah 273 (98,9\%) responden, penerimaan pasien dilakukan secara terjadwal sejumlah $150(54,3 \%)$ responden, dan pilihan skrining dan pengaturan pasien terbanyak berjumlah lima, dengan jumlah $90(32,6 \%)$ responden.

Tabel 3 memperlihatkan tingkat kecemasan dokter gigi yang dibagi atas empat kategori. Kategori dengan persentase tertinggi ialah kecemasan sedang sebanyak $150(54,3 \%)$ responden.

Tabel 4 memperlihatkan hasil tabulasi silang antara tingkat kecemasan dengan karakteristik responden penelitian dan kesiapan dokter gigi. Tabulasi silang antara tempat praktik dan tingkat kecemasan menunjukkan bahwa persentase tertinggi pada ketiga tempat praktik ialah tingkat kecemasan sedang dengan jumlah 23 $(51,1 \%)$ responden yang berpraktik di rumah sakit/puskesmas, $54(57,4 \%)$ responden yang berpraktik di klinik, dan 73 $(53,3 \%)$ responden yang melakukan praktik pribadi. Pada responden yang telah menerima vaksinasi Covid-19 maupun yang tidak menerima vaksinasi Covid-19, persentase tertinggi terdapat pada kategori kecemasan sedang dengan jumlah $147 \quad(53,9 \%)$ responden untuk yang telah menerima vaksinasi dan 3 (100\%) responden yang tidak menerima vaksinasi.

Tabel 1. Jumlah dan karakteristik responden

\begin{tabular}{lcc}
\hline Profil & Frekuensi & Persentase (\%) \\
\hline Jenis kelamin & & \\
$\quad$ Laki-laki & 99 & 35,9 \\
$\quad$ Perempuan & 177 & 64,1 \\
Usia & & \\
20-30 tahun & 110 & 39,9 \\
31-40 tahun & 79 & 28,6 \\
41-50 tahun & 36 & 13,0 \\
51-60 tahun & 47 & 17,0 \\
>60 tahun & 4 & 1,4 \\
Penyakit sistemik penyerta (Komorbid) & & 9,1 \\
Ada & 25 & 90,9 \\
Tidak ada & 251 & 100,0 \\
Total & 276 & \\
\hline
\end{tabular}


Tabel 2. Kesiapan dokter gigi dalam menghadapi pandemi Covid-19

\begin{tabular}{lcc}
\hline Profil & Frekuensi & Persentase (\%) \\
\hline Tempat praktik & & \\
$\quad$ Rumah Sakit/Puskesmas & 45 & 16,3 \\
Klinik & 94 & 34,1 \\
Praktik pribadi & 137 & 49,6 \\
Lama praktik sebagai dokter gigi & & \\
0 - 5 tahun & 114 & 41,3 \\
6 - 10 tahun & 60 & 21,7 \\
11 - 15 tahun & 35 & 12,7 \\
>15 tahun & 67 & 24,3 \\
Telah menerima vaksinasi Covid-19 & & \\
Ya & 273 & 98,9 \\
Tidak & 3 & 1,1 \\
Penerimaan pasien & & 45,7 \\
Walk-in & 126 & 54,3 \\
Terjadwal & 150 & \\
Jumlah skrining dan pengaturan pasien & & 2,9 \\
1 pilihan skrining & 8 & 4,0 \\
2 pilihan skrining & 11 & 9,1 \\
3 pilihan skrining & 25 & 21,7 \\
4 pilihan skrining & 60 & 32,6 \\
5 pilihan skrining & 90 & 29,7 \\
6 pilihan skrining & 82 & 100,0 \\
Total & 276 &
\end{tabular}

Tabel 3. Tingkat kecemasan dokter gigi

\begin{tabular}{lcc}
\hline $\begin{array}{c}\text { Tingkat } \\
\text { kecemasan }\end{array}$ & Frekuensi & $\begin{array}{c}\text { Persentase } \\
(\boldsymbol{\%})\end{array}$ \\
\hline Tidak ada & 7 & 2,5 \\
Ringan & 55 & 19,9 \\
Sedang & 150 & 54,3 \\
Berat & 64 & 23,2 \\
Total & 276 & 100,0 \\
\hline
\end{tabular}

Tabulasi silang antara tingkat kecemasan dan lama praktik sebagai dokter gigi, seluruh kategori yaitu rentang 0-5 tahun, 610 tahun, 11-15 tahun, dan $>15$ tahun menunjukkan bahwa persentase tertinggi terdapat pada tingkat kecemasan sedang dengan jumlah masing-masing 57 (50\%), 33 $(55 \%), 21(60 \%)$, dan $39(58,2 \%)$ responden. Persentase tertinggi dari tingkat kecemasan pada pasien walk in ialah pada kecemasan sedang sejumlah $62(49,2 \%)$ responden. Hal yang serupa juga didapatkan pada pasien terjadwal yaitu persentase tertinggi berada pada kecemasan sedang sejumlah $88(58,7 \%)$ responden. Frekuensi tingkat kecemasan yang dikategorikan berdasarkan skrining dan pengaturan pasien memiliki persentase tertinggi pada kecemasan sedang di semua rentang skrining.

Tabel 5 memperlihatkan hasil uji korelasi Spearman yang menunjukkan bahwa tidak terdapat hubungan antara jenis kelamin, usia, tempat praktik, telah menerima vaksinasi Covid-19, penyakit sistemik penyerta (komorbid), lama praktik sebagai dokter gigi, dan penerimaan pasien dengan tingkat kecemasan dokter gigi dalam menghadapi pandemi Covid-19 dengan nilai signifikansi lebih besar dari 0,05 $(\mathrm{p}>0,05)$ yaitu secara berurut ialah 0,$512 ; 0,460$; 0,$210 ; 0,981 ; 0,363 ; 0,430$; dan 0,383.

Nilai signifikansi yang diperoleh untuk 
skrining dan pengaturan pasien yaitu 0,034 $(\mathrm{p}<0,05)$, yang menunjukkan bahwa terdapat hubungan antara jumlah skrining dan pengaturan pasien dengan tingkat kecemas-an dokter gigi dalam menghadapi pandemi Covid-19. Nilai koefisien korelasi (r) yang diperoleh yaitu $-0,128$, yang menunjukkan bahwa terdapat hubungan bertolak belakang sangat lemah antara jumlah skrining dan pengaturan pasien dengan tingkat kecemasan dokter gigi dalam menghadapi pandemi Covid-19. Dapat dikatakan bahwa semakin banyak jumlah skrining dan pengaturan pasien maka tingkat kecemasan dokter gigi semakin rendah, demikian pula sebaliknya.

Tabel 4. Tabulasi silang antara tingkat kecemasan dengan karakteristik responden penelitian dan kesiapan dokter gigi

\begin{tabular}{llccccc}
\hline & & \multicolumn{5}{c}{ Tingkat kecemasan } \\
& & Tidak ada & Ringan & Sedang & Berat & Total \\
\hline Tempat praktik & $\begin{array}{l}\text { Rumah Sakit/ } \\
\text { Puskesmas }\end{array}$ & $0(0,0 \%)$ & $8(17,8 \%)$ & $23(51,1 \%)$ & $14(31,1 \%)$ & $45(100 \%)$ \\
& Klinik & $2(2,1 \%)$ & $18(19,2 \%)$ & $54(57,4 \%)$ & $20(21,3 \%)$ & $94(100 \%)$ \\
& Praktik pribadi & $5(3,6 \%)$ & $29(21,2 \%)$ & $73(53,3 \%)$ & $30(21,9 \%)$ & $137(100 \%)$ \\
Telah menerima & Ya & $7(2,6 \%)$ & $55(20,1 \%)$ & $147(53,9 \%)$ & $64(23,4 \%)$ & $273(100 \%)$ \\
vaksinasi Covid-19 & Tidak & $0(0,0 \%)$ & $0(0,0 \%)$ & $3(100 \%)$ & $0(0,0 \%)$ & $3(100 \%)$ \\
Lama praktik sebagai & $0-5$ tahun & $4(3,5 \%)$ & $25(21,9 \%)$ & $57(50 \%)$ & $28(24,6 \%)$ & $114(100 \%)$ \\
dokter gigi & $6-10$ tahun & $0(0,0 \%)$ & $11(18,3 \%)$ & $33(55 \%)$ & $16(26,7 \%)$ & $60(100 \%)$ \\
& $11-15$ tahun & $1(2,9 \%)$ & $4(11,4 \%)$ & $21(60 \%)$ & $9(25,7 \%)$ & $35(100 \%)$ \\
& $>15$ tahun & $2(3 \%)$ & $15(22,4 \%)$ & $39(58,2 \%)$ & $11(16,4 \%)$ & $67(100 \%)$ \\
Penerimaan pasien & Walk in & $4(3,2 \%)$ & $25(19,8 \%)$ & $62(49,2 \%)$ & $35(27,8 \%)$ & $126(100 \%)$ \\
& Terjadwal & $3(2 \%)$ & $30(20 \%)$ & $88(58,7 \%)$ & $29(19,3 \%)$ & $150(100 \%)$ \\
Jumlah pilihan skrining & 1 & $0(0,0 \%)$ & $1(12,5 \%)$ & $4(50 \%)$ & $3(37,5 \%)$ & $8(100 \%)$ \\
dan pengaturan pasien & 2 & $0(0,0 \%)$ & $2(18,2 \%)$ & $3(27,3 \%)$ & $6(54,5 \%)$ & $11(100 \%)$ \\
& 2 & $0(0,0 \%)$ & $5(20 \%)$ & $14(56 \%)$ & $6(24 \%)$ & $25100 \%)$ \\
& 3 & $2(3,3 \%)$ & $9(15 \%)$ & $34(56,7 \%)$ & $15(25 \%)$ & $60(100 \%)$ \\
& 4 & $3(3,3 \%)$ & $18(20 \%)$ & $50(55,6 \%)$ & $19(21,1 \%)$ & $90(100 \%)$ \\
& 5 & $2(2,4 \%)$ & $20(24,4 \%)$ & $45(54,9 \%)$ & $15(18,3 \%)$ & $82(100 \%)$ \\
\hline
\end{tabular}

Tabel 5. Hubungan antara tingkat kecemasan dan kesiapan dokter gigi

\begin{tabular}{llc}
\hline Tingkat kecemasan & & \\
\hline Tempat praktik & Correlation Coefficient & $-0,076$ \\
& Sig. (2-tailed) & 0,210 \\
Telah menerima vaksinasi & Correlation Coefficient & -0.001 \\
Covid-19 & Sig. (2-tailed) & 0.981 \\
Lama praktik & Correlation Coefficient & $-0,021$ \\
& Sig. (2-tailed) & 0,730 \\
Penerimaan pasien & Correlation Coefficient & $-0,053$ \\
\multirow{2}{*}{ Jumlah skrining dan } & Sig. (2-tailed) & 0,383 \\
pengaturan pasien & Correlation Coefficient & $-0,128^{*}$ \\
\hline
\end{tabular}




\section{BAHASAN}

Penelitian ini merupakan suatu studi analitik dengan desain potong lintang yang bertujuan untuk mengetahui hubungan antar tingkat kecemasan dan kesiapan dokter gigi dalam menghadapi pandemi Covid-19 di Bali. Penelitian dilakukan pada tanggal 19 Agustus s/d 23 Oktober 2021 dengan partisipasi 276 orang dokter gigi di Bali yang memenuhi kriteria inklusi. Pada penelitian ini digunakan kuesioner yang telah dilakukan uji validitas dan reliabilitas, disebar secara online, terdiri dari pertanyaan mengenai data demografi, kesiapan dokter gigi, dan tingkat kecemasan dokter gigi dalam menghadapi pandemi Covid-19 di Bali.

Dokter gigi digolongkan sebagai pekerjaan berisiko tinggi terkena penyakit menular karena dokter gigi bekerja dekat dengan rongga mulut pasien. Munculnya wabah Covid-19 membawa tantangan dan tanggung jawab baru bagi para dokter gigi. ${ }^{6}$ Implikasi psikologis seperti ketakutan dan kecemasan merupakan hal wajar dalam pandemi, terutama jika terdapat jumlah individu terinfeksi dan angka kematian meningkat tajam. Studi mengenai wabah penyakit menular serupa sebelumnya seperti sindrom pernapasan akut yang parah (SARS) menunjukkan berbagai faktor yang menyebabkan trauma psikologis pada petugas kesehatan. Dampak penyebaran cepat dari Covid-19 saat ini mengakibatkan tekanan dan kecemasan psikologis yang cukup besar. ${ }^{13}$

Hasil penelitian ini mendapatkan bahwa tingkat kecemasan dokter gigi paling tinggi ialah kecemasan sedang/moderate sebesar $54,3 \%$ (Tabel 3). Hasil serupa juga dilaporkan pada penelitian yang membahas mengenai kecemasan terkait Covid-19 di antara petugas kesehatan di Kamerun yang mengungkapkan bahwa $41,8 \%$ responden masuk dalam kategori kecemasan sedang. ${ }^{14}$ Penelitian di Itali Utara juga menguraikan mayoritas praktisi gigi melaporkan kecemasan ringan $(37,4 \%)$ dan sedang $(23,6 \%){ }^{15}$

Kecemasan dapat terjadi dan dialami oleh manusia karena dipengaruhi oleh berbagai faktor. Studi yang dilakukan di Israel memberikan evaluasi mengenai tingkat tekanan psikologis yang dialami oleh dokter gigi selama wabah pandemi Covid-19 dan menilai faktor-faktor yang mungkin terkait, yaitu berada dalam kelompok risiko, ketakutan tertular Covid-19 dari pasien, dan menerima pengetahuan profesional yang cukup tentang Covid-19, dan faktor psikologis, yaitu kelebihan beban subjektif dan efikasi diri. ${ }^{16}$

Consolo et $\mathrm{al}^{15}$ meneliti aspek epidemiologi dan reaksi psikologis dokter gigi terhadap Covid-19 dengan merancang kuesioner yang terdiri dari pertanyaan berkaitan karakteristik sosio-demografi responden, sikap dan persepsi dokter gigi terhadap Covid-19, serta pengendalian infeksi di klinik gigi. Penelitian tersebut juga difokuskan pada dampak psikologis dokter gigi dan perubahan praktik pada kedokteran gigi sehari-hari. Kuesioner ini diberikan selama periode kritis pandemi di Itali Utara dan hasil penelitian melaporkan adanya penutupan atau pengurangan praktik, tingkat kekhawatiran yang tinggi tentang masa depan profesi dan harapan bantuan pendanaan bagi praktisi gigi. ${ }^{15}$

Pada penelitian ini, tingkat kecemasan dokter gigi dalam menghadapi pandemi Covid-19 dihubungkan dengan beberapa faktor yaitu tempat praktik, penerimaan vaksinasi Covid-19, lama praktik, penerimaan pasien, serta jumlah skrining dan pengaturan pasien. Hasil penelitian mengungkapkan adanya hubungan antara jumlah skrining dan pengaturan pasien dengan tingkat kecemasan dokter gigi dalam menghadapi pandemi Covid-19 dengan nilai koefisien korelasi (r) yaitu -0,128 (Tabel 5). Hal ini menunjukkan bahwa terdapat hubungan bertolak belakang yang sangat lemah antara jumlah skrining dan pengaturan pasien dengan tingkat kecemasan dokter gigi dalam menghadapi pandemi Covid-19. Dengan kata lain semakin banyak jumlah skrining dan pengaturan pasien yang dilakukan dalam praktik dokter gigi maka tingkat kecemasan dokter gigi semakin rendah dan demikian pula sebaliknya.

Strategi dan mekanisme koping sangat penting dipraktikkan pada dokter gigi dalam menghadapi kecemasan terhadap Covid-19 agar tetap dapat melakukan pekerjaannya 
dengan tenang dan efisien. Kecemasan yang dimiliki dokter gigi tentang terinfeksi Covid-19 dapat sangat dikurangi jika dokter gigi dan petugas kesehatan gigi dengan cermat mengikuti rekomendasi terkait yang dikeluarkan oleh otoritas pengatur. Hal ini termasuk protokol kontrol infeksi silang bersama dengan beberapa tindakan pencegahan tambahan dalam kasus tertentu saat pasien datang dengan gejala Covid-19 yang perlu dicurigai. ${ }^{13}$ Pemahaman yang lebih baik tentang transmisi dan implikasinya dalam kedokteran gigi dapat membantu mengidentifikasi dan memperbaiki kelalaian yang mungkin terjadi dalam praktik kedokteran gigi di era pandemi Covid-19. ${ }^{6}$

Pada penelitian ini, tidak terdapat hubungan antara tingkat kecemasan dengan tempat praktik, lama praktik, penerimaan pasien, dan penerimaan vaksin. Hal ini dapat terjadi karena beberapa praktik tambahan yang telah direkomendasikan oleh CDC Center of Disease Control and Prevention (CDC) dan PDGI mengenai pencegahan penularan silang virus dan pengendalian infeksi tambahan untuk menjaga keamanan dokter gigi saat melakukan praktik selama wabah pandemi Covid-19. ${ }^{12,17}$

Hasil penelitian ini menunjukkan bahwa sebanyak 98,9\% responden telah menerima vaksinasi Covid-19 (Tabel 4). Perez-Arce et al $^{18}$ dalam penelitiannya memaparkan bahwa responden merasakan depresi dan kecemasan yang lebih sedikit setelah menerima dosis awal vaksinasi. Kontribusi keseluruhan dari responden yang telah menerima vaksinasi pada peningkatan kesehatan mental berpotensi jauh lebih besar karena tidak hanya memengaruhi mereka yang divaksinasi tetapi juga yang tidak divaksinasi. Individu yang tidak divaksinasi mungkin masih mendapat manfaat dari penurunan tingkat prevalensi Covid-19 dalam populasi. Individu yang telah divaksinasi mungkin merasa kekhawatirannya berkurang akan terinfeksi, dapat mengambil manfaat lebih banyak melakukan antivitas sosial-ekonomi karena risiko penyakit yang lebih rendah. ${ }^{18}$

Keterbatasan dalam penelitian ini antara lain ialah tingkat partisipasi responden yang dapat digolongkan masih cukup rendah. Kuesioner telah disebar ke seluruh anggota PDGI cabang Denpasar dan Badung, namun hanya terdapat 276 responden yang mengisi kuesioner dari keseluruhan dokter gigi yang terdaftar sejumlah 872 orang. Hal ini dapat meningkatkan risiko bias pada hasil penelitian. Sebagian besar proses pengambilan data dilakukan secara dalam jaringan (daring) sehingga penulis tidak dapat melakukan verifikasi jawaban yang diberikan oleh responden dengan kondisi tempat praktik sebenarnya. Mengingat hal tersebut, hasil penelitian ini harus ditafsirkan secara lebih berhati-hati.

Pada penelitian ini, tidak terdapat hubungan antara tingkat kecemasan dengan tempat praktik, lama praktik, penerimaan pasien, dan penerimaan vaksin. Hal ini dapat disebabkan penelitian ini dilakukan pada saat kasus Covid-19 sudah mulai melandai dan berkurang, sehingga persepsi dokter gigi dan kecemasannya sudah berubah. Hal lainnya yang juga dapat memengaruhi ialah keterbatasan literatur terkait kecemasan dokter gigi di era pandemi Covid-19 serta keadaan mengenai virus Covid-19 yang masih terus berubah-ubah.

Faktor-faktor yang dihubungkan dengan tingkat kecemasan yang diselidiki dalam penelitian ini masih terbatas. Di masa depan dapat dilakukan penelitian lebih lanjut untuk melihat lebih banyak faktor yang berhubungan dengan kecemasan untuk memperluas pemahaman mengenai kecemasan dan faktor yang memengaruhinya terkait dengan dokter gigi dalam menghadapi pandemi Covid-19.

\section{SIMPULAN}

Terdapat hubungan bertolak belakang antara tingkat kecemasan dengan kesiapan dokter gigi yang dinyatakan dalam jumlah skrining dan pengaturan pasien dalam menghadapi pandemi Covid-19 di Bali. Semakin banyak jumlah skrining dan pengaturan pasien maka tingkat kecemasan dokter gigi semakin rendah, demikian pula sebaliknya.

Tingkat kecemasan yang paling banyak dialami oleh dokter gigi di Bali terkait pandemi Covid-19 ialah kecemasan sedang/ 
moderate. Tidak terdapat hubungan antara jenis kelamin, usia, tempat praktik, telah menerima vaksin Covid-19, penyakit sistemik penyerta (komorbid), lama praktik sebagai dokter gigi, dan penerimaan pasien dengan tingkat kecemasan dokter gigi dalam menghadapi pandemi Covid-19.

\section{Konflik Kepentingan}

Penulis menyatakan tidak terdapat konflik kepentingan dalam studi ini.

\section{Ucapan terima kasih}

Ucapan terima kasih ditujukan kepada PDGI Badung, PDGI Denpasar, dan Universitas Udayana.

\section{DAFTAR PUSTAKA}

1. Nanda KDS, Nanda J. Recommendations and management in dental practice during corona virus COVID-19. Open Dent J. 2020;14(1):191-3.

2. Kemenkes RI. Pedoman Pencegahan dan Pengendalian Coronavirus Disease (COVID-19). Germas. 2020. p. 1-115.

3. CDC. Centers for Disease Control and Prevention. 2020. Symptoms of coronavirus (COVID-19) [Internet]. Available from: https://www.cdc.gov/coronavirus/2019ncov/symptoms-testing/symptoms.html

4. CDC. Centers for Disease Control and Prevention. 2020. How coronavirus spreads CDC [Internet]. Available from: https://www.cdc.gov/coronavirus/2019ncov/transmission/index.html

5. Farooq I, Ali S. COVID-19 outbreak and its monetary implications for dental practices, hospitals and healthcare workers. Postgrad Med J. 2020;0(0):1-2.

6. Ge ZY, Yang LM, Xia JJ, Fu XH, Zhang YZ. Possible aerosol transmission of COVID-19 and special precautions in dentistry. J Zhejiang Univ Sci B. 2020; 5(1):361-8.

7. World Health Organization. WHO Coronavirus Disease (COVID-19) Dashboard [Internet]. Covid-19 Dashboard. 2020. p. 1-1. Available from: https://covid19. who.int/

8. Peta Risiko|Covid19.go.id [Internet]. Available from: https://covid19.go.id/ peta-risiko

9. Peta Sebaran COVID-19|Satgas Penanganan
COVID-19 [Internet]. 2021. Available from: https://covid19.go.id/petasebaran-covid19

10. Bai YM, Lin CC, Lin CY, Chen JY, Chue CM, Chou P. Survey of stress reactions among health care workers involved with the SARS outbreak. Psychiatr Serv. 2004;55(9):1055-7.

11. Seneviratne CJ, Lau MWJ, Goh BT. The role of dentists in COVID-19 Is beyond dentistry: voluntary medical engagements and future preparedness. Front Med. 2020;7(566):1-7.

12. Amtha R. Panduan Dokter Gigi dalam Era New Normal. Pengurus Besar Persatuan Dokter Gigi Indonesia, 2019; p. 1-94.

13. Ahmed MA, Jouhar R, Ahmed N, Adnan S, Aftab M, Zafar MS, et al. Fear and practice modifications among dentists to combat novel coronavirus disease (COVID-19) outbreak. Int J Environ Res Public Health. 2020;17(2821):1-11.

14. Mboua CP, Keubo FRN, Fouaka SGN. Anxiety and depression associated with the management of COVID-19 among healthcare workers in Cameroon. Evol Psychiatr. 2021;86(1):1-16.

15. Consolo U, Bellini P, Bencivenni D, Iani C, Checchi V. Epidemiological aspects and psychological reactions to COVID-19 of dental practitioners in the Northern Italy districts of modena and reggio emilia. Int J Environ Res Public Health. 2020;17(10):3459.

16. Shacham M, Hamama-Raz Y, Kolerman R, Mijiritsky O, Ben-Ezra M, Mijiritsky E. COVID-19 factors and psychological factors associated with elevated psychological distress among dentists and dental hygienists in Israel. Int J Environ Res Public Health. 2020;17(8):2900.

17. CDC. Dental Settings |CDC [Internet]. Interim infection prevention and control guidance for dental settings during the COVID-19 response. 2020. Available from: https://www.cdc.gov/corona virus/2019-ncov/hcp/dentalsettings.html

18. Perez-Arce F, Angrisani M, Bennett D, Darling J, Kapteyn A, Thomas K. COVID19 vaccines and mental distress. PLoS One. 2021;16(9):1-11. 